\title{
Leaving the Reservation: Reconstructing Identity in Sherman Alexie's The Absolutely True Diary of a Part-Time Indian
}

\author{
Li Ping Chang ${ }^{1, *}$, Shu Yuan Chuang ${ }^{1}$, Chih Ting Wang ${ }^{1}$, Han Ting Chang ${ }^{1}$, Mei Han Chen $^{1}$, Chu Hsien Chang ${ }^{1} \&$ \\ Yin Chi Chu ${ }^{1}$ \\ ${ }^{1}$ Department of Applied Foreign Languages, National Taipei College of Business, Taipei, Taiwan \\ *Correponding author: Department of Applied Foreign Languages, National Taipei College of Business, Taipei, \\ Taiwan. E-mail: floraliping@webmail.ntcb.edu.tw
}

Received: December 22, 2013 Accepted: January 27, $2014 \quad$ Online Published: February 17, 2014

doi:10.5430/wjel.v4n1p1

URL: http://dx.doi.org/10.5430/wjel.v4n1p1

\begin{abstract}
Sherman Alexie is an acclaimed Native American author who writes about growing up on the Spokane Indian reservation and the harsh realities of widespread poverty and alcoholism. This paper aims to examine his reconstruction of Native American identity in his young adult novel, The Absolutely True Diary of a Part-Time Indian. This book presents a Native American's education, culture, and wounds through the eyes of a teenage boy named Arnold. The phrase "absolutely true diary" hints at the semi-autobiographical nature of Alexie's novel; like Arnold, Alexie grew up on the Spokane Indian Reservation and transferred to the all-white high school in Reardon to escape the hopelessness of the rez. The words "part-time" signify Arnold's struggle to reconcile his disparate experiences in the white world and the Indian world. Caught between the two, he must reconstruct his Native American identity to find his own place in the world.
\end{abstract}

Keywords: Native American identity; alcoholism; reservation life

\section{Introduction}

Sherman Alexie is an acclaimed Native American poet, novelist, and filmmaker. Born in 1966, he grew up on the Spokane/Coeur d'Alene tribal reservation in Wellpinit, Washington with his family. While in college, a teacher recommended Native American Joseph Bruchac's book of poetry, Songs from This Earth on Turtle's Back (1983), which inspired Alexie to write his own poems. Alexie's first collection, The Business of Fancydancing (1992), garnered praise for him as "one of the major lyric voices of our time" from the New York Times.(Note 1) Alexie went on to win numerous awards, including The National Book Award, the PEN/Malamud Award, and the American Book Award for his fiction and poetry. His semi-autobiographical young adult novel, The Absolutely True Diary of a Part-Time Indian (Diary 2007), won the Boston Globe-Horn Book Award in 2008, the California Young Reader Medal in 2010, and in 2008 was listed on the "Top Ten Best Books for Young Adults” put out by the Young Adult Library Services Association.

In Diary, Alexie explores tensions between the individual and the tribe, as well as between whites and Indians; at the same time he looks at "how individuals can influence history for the better. Small acts do make a difference" (Bruce, 2008, p. 117). This article will examine how Alexie's protagonist Arnold, and Alexie himself, attempt to reconstruct Indian identity in the face of the poverty and alcoholism that are endemic to the reservation life shown in Diary. As well, this novel, like all of Alexie's works, demolishes the romantic portrayal of the Indian as "mystic naturist", presenting a much more painful picture of the contemporary Native American (Korsmo, 2011, p. 4).

Alexie's fiction exposes the reality of reservation life. As he says in Diary, the reservations were intended to be prisons (Alexie, 2009, p. 216). They were part of a system to deprive Native Americans of their spiritual heritage as well as their land. Alexie writes that: "[w]e Indians have LOST EVERYTHING. We lost our native land, we lost our languages, we lost our songs and dances. We lost each other. We only know how to lose and be lost” (ibid., p. 173). As Joshua B. Nelson (2010) states, "[i]n the reservation era, the United States created rural ghettos where Indians could be contained, surveilled by the state --- kept in reserve with all due legality and beneficence (p. 44). 
In Diary, Alexie shows the reservation through the eyes of his protagonist Arnold, who represents Alexie himself. Like Arnold, Alexie was born with hydrocephalus (also known as "water on the brain"), for which he had brain surgery when he was six months old. As a result of this condition he had seizures and an enlarged head, which made him a target for bullies on the reservation. He was also intelligent, he loved to read, and he transferred from the reservation school to the all-white school at Reardon in high school. Alexie thus reflects on his own inner conflicts through Arnold, who feels caught between the whites and the Indians as he goes back and forth between the reservation and his school: "[t]raveling between Reardan and Wellpinit, between the little white town and the reservation, I always felt like a stranger...I was half Indian in one place and half white in the other” (Alexie, 2009, p. 118).

The tension Arnold feels is not only due to his inner conflict; except for his family and his father's friend Eugene, the other Indians on the reservation feel betrayed by Arnold's decision to go to school in Reardon, as if he has sided with the whites against them. They regard him as a traitor to the tribe. Even Arnold's best friend Rowdy, who has always protected him from bullying, feels betrayed. Rowdy yells at Arnold, "You always thought you were better than me" (ibid., p. 53), and is so upset when Arnold tells him about going to school in Reardon that he screams. When Arnold asks Rowdy to come too, he punches Arnold. But what Arnold sees is that Rowdy is "screaming with his eyes" (ibid., p. 52). The tough, fearless Rowdy is afraid to leave the rez. Arnold is also afraid, but Rowdy's fear has turned to hatred. That hatred will extend to Arnold.

In Diary, Native Americans are not romanticized. Alexie is unsparing in his descriptions of abuse and intolerance on the reservation; he comments on "the old days" when "Indians used to be forgiving of any kind of eccentricity" and "weird people were celebrated" (ibid., p. 155), while nowadays anyone who is different is beaten up. Alexie describes the atmosphere that fosters such cruelty as due to poverty, displacement, and widespread alcoholism. Part of Rowdy's problem is that his father is a mean drunk, who beats on him and his mother. The teacher who tells Arnold that he must leave the reservation says that "Rowdy is just going to get meaner and meaner" (ibid., p. 41), and Arnold notes that when Rowdy comes to school with a black eye, he gives "black eyes to two kids picked at random” (ibid.). In other words, Arnold/Alexie knows exactly what Rowdy's problems are, and where they are likely to lead. Unlike Alexie the writer, Arnold is a cartoonist. While Rowdy protects him from bullying, through his cartoons Arnold gives Rowdy "other worlds to live inside" (ibid., p. 23), a place and a way to feel happy and laugh. This parallels what Alexie the author is trying to do with his stories - to give hope to his readers, whether they are Native American or anyone else who is struggling against despair.

But Arnold cannot convince Rowdy to come with him to Reardon, and there is no way for Arnold to change the whole reservation and turn it into a good place for Rowdy to be. Arnold leaves to save himself, telling his friend that he'll die if he stays. Throughout the rest of the book, Arnold reiterates how important it is to leave the reservation, and equates staying there with dying: "I knew that staying on the rez would have killed me, too" (ibid., p. 216). Therefore, Arnold has an urge to leave the reservation. To Arnold (Alexie), "reading and writing as his ticket out of his reservation's stifling poverty and intellectual entropy, but intentionally or not, it's a round-trip package (Nelson, 2010, p. 47).

\section{Leaving the Reservation}

The U.S. government may present its Indian reservations as a way to protect Native American culture and identity, but as Alexie experienced life there, the reservation separated and alienated Native Americans from the rest of the world. Alexie has delineated "the reservation as a center of Indian identity in three of his novels" (The Lone Ranger and Tonto Fistfight in Heaven [1993], Reservation Blues [1995], and The Absolutely True Diary of a Part-Time Indian [2009]) (Connette, Abstract), presenting the reservation as another way of marginalizing Indians.

The Spokane reservation where Alexie grew up and Arnold lives is impoverished and alcoholism is rampant. Its inhabitants might dream of what they want to do in life, but they have no way to achieve these dreams. When the Indians on the reservation vilify him and call him a "white lover" for transferring to a white school, Arnold says: "Indians have forgotten that reservations were meant to be death camps" (Alexie, 2009, p. 217). Although leaving the reservation might mean losing touch with traditional Native American culture, in Alexie's world it is the only way to escape a killing despair. As Arnold's teacher says: "You're going to find more and more hope the farther you walk away from this sad, sad reservation” (ibid., p. 43).

As well as the omnipresent poverty and lack of education, Arnold blames alcohol for the problems on the reservation. When his white friend Gordy gives him a book by Tolstoy that says "every unhappy family is unhappy in its own 
way”, Arnold disagrees. He decides that “Tolstoy didn’t know Indians. And he didn't know that all Indian families are unhappy for the same exact reason: the fricking booze" (ibid., p. 200).

Arnold's father drinks to avoid facing the financial problems that overwhelm him. Unlike Rowdy's father, Arnold's father would never hit his children or his wife, but his inability to stop drinking is a source of shame and unhappiness to Arnold. In the year in which Diary takes place, Arnold's grandmother, who has never touched alcohol, is killed by a drunk driver; Arnold's father's best friend Eugene is shot and killed in a drunken argument; and Arnold's sister Mary and her new husband die when their trailer catches fire because they are too drunk to wake up and escape the flames. So three of the people he loves best in the world die because of alcohol abuse, and Arnold knows that another five to fifteen Spokanes will die within the year "and that most of them would die because of booze" (ibid., p. 216).

At the cemetery, Arnold weeps for all of his tribe, who "were slowly killing themselves and I wanted them to live. I wanted them to get strong and sober and get the hell off the rez" (ibid.). In his mind, drunkenness and living on the rez are inextricably entwined. And despite his guilt for leaving the only Indian world he knows, he vows to keep faith with his own dreams:

I wept because I was the only one who was brave and crazy enough to leave the rez. I was the only one with enough arrogance. I wept and wept and wept because I knew that I was never going to drink because I was never going to kill myself and because I was going to have a better life out in the white world. (ibid., p. 217)

Despite the character Arnold's determination never to drink, Alexie the man had a different story: he became an alcoholic after he left the reservation. As he says in an interview: "Well, I'm an alcoholic...my family is filled with alcoholics. My tribe is filled with alcoholics. The whole race is filled with alcoholics. For those Indians who try to pretend it's a stereotype, they're in deep, deep denial.” (Note 2)

\section{Native Americans and Alcohol}

According to the Diagnostic and Statistical Manual of Mental Disorders, alcohol abuse can lead to a failure to fulfill social obligations, to dangerous behavior such as drunk driving or violent aggression, and to the resulting legal problems that such behavior can cause. Since people may drink to alleviate emotional pain, lift depression, and forget their problems, they often continue to drink "despite having persistent or recurrent social or interpersonal problems caused or exacerbated by the effects of the alcohol." (Note 3)

Laurence A. French and Jim Hornbuckle (1980), state that alcoholism results from a complicated interaction among "physiological, psychological, and sociological factors" (p. 276). The American Medical Association agrees that alcoholism comes from the interplay of the above factors.

As regards physiology, recent research has shown that people whose parents have drinking problems may become alcoholic more easily than other people. Dr. Ting-Kai Li of the Indiana Alcohol Research Center states that their experiments have identified genes that protect against intemperate drinking, and that "We have shown that Native Americans, who have a high rate of alcoholism, do not have these protective genes." (Note 4) Stephen F. Evans (2001) points out that "a number of his [Alexie's] Indian characters themselves fear a genetic inheritance that may include the propensity toward alcoholism” (p. 12).

The psychological factors that lead to alcoholism include low self-esteem, emotional pain, and high stress, and "drunkenness can serve as an excuse for behavior which would have been inexcusable if the person were sober" (Room, 2001, p. 189). All of the psychological factors are exacerbated by poverty. Arnold's father is a good example of this: “[w]hen the holidays rolled around, we didn't have any money for presents, so Dad did what he always does when we don't have enough money” (Alexie, 2009, p. 150), he disappeared for a couple of days, spending what money he had to get drunk. Arnold is well aware that the poverty and alcoholism that blight the reservation are connected, and that despair came before his father's drinking problems. Thinking about his father's musical talents, and that he should have been a musician, Arnold says:

But we reservation Indians don't get to realize our dreams. We don't get those chances. Or choices. We're just poor. That's all we are...It sucks to be poor, and it sucks to feel that you somehow deserve to be poor. You start believing that you're poor because you're stupid and ugly. And then you start believing that you're stupid and ugly because you're Indian. And because you're Indian you start believing you're destined to be poor. It's an ugly circle and there's nothing you can do about it. (ibid., p. 13)

As well as the psychological "ugly circle" of low self-esteem, poverty, and despair, everyone on the reservation has 
to contend with an environment where drunkenness is common. Of course alcohol may be used in a celebratory way as well, to make a gathering festive, to make people feel more connected to each other, and/or to underscore the importance of a ritual. But when his relatives begin drinking at his sister Mary's wake, Arnold does not feel connected to them, but furious at them. He has to leave because "everybody would be drinking booze and getting drunk and stupid and sad and mean” (ibid., p. 211), which seems to him like an idiot's way of mourning Mary's death from being too drunk to get out of a burning trailer. Even though Arnold understands that his relatives are drinking to dull their pain, that his "sister's death made everybody remember all the deaths in their life" (ibid., p. 212) he finds their drinking unbearable. He gets more comfort from his white friends at school, who are worried for him and upset over this latest loss in his life ("We'd lost my grandmother and Eugene. How much loss were we supposed to endure?” [ibid., p. 171]). At this point he realizes with some surprise that these white students and teachers care for him, that they are his friends.

Although he cannot bear to be around his relatives and finds sympathy in the white world instead, Arnold immediately collapses into guilt when Rowdy accuses him of being the cause of Mary's death. Rowdy tells Arnold: "Your sister is dead because you left us. You killed her" (ibid., p. 211). While Arnold knows that he didn’t directly kill Mary, he feels responsible for her death. He believes that she never would have left the reservation to live in a trailer and die there if Arnold hadn't left the rez first. He thinks: "She burned to death because I had decided I wanted to spend my life with white people" (ibid.).

In Alexie's real-life escape from the reservation, he may have carried a burden of guilt. Arnold clearly feels guilty over leaving his friend Rowdy to his fate, which leads him to taking the blame for his sister's death as well; this guilt may mirror the author's guilt at his flight from his home. Getting a better education, living in the white world, and having a hatred of the effects of alcohol did not keep Alexie from having drinking problems himself. When he was first in college he had hoped to be a doctor, then a lawyer, but he was unhappy with both choices. Possibly his unhappiness combined with guilt over leaving the reservation and not having anything to give back to the people there, and led him to alleviate the pain in a way that was familiar, through alcohol. During his "desperate years" he drank heavily; and he also began to write. He wrote his first book of poetry, The Business of Fancydancing, as well as his novel The Lone Ranger and Tonto Fistfight in Heaven (which his film Smoke Signals is based upon) during his alcoholic years. His success as a writer, with something important to say to the people he had left behind, may also have helped him quit drinking. In an interview he says that alcoholism "is an everyday part of my life" so he wrote about it. But he says that he did so not only for "narrative purposes, but partly with the social hope that by writing about it, maybe it'll help people get sober, and it has. I’ve heard from them.” (Note 5)

\section{Relationships between Native Americans and Whites}

Liu Kedong (2011) regards Arnold as the image of the "postindian warrior" (p. 92) coined by Gerald Vizenor. The postindian warrior Arnold goes to the white school in Reardon, then, to escape the hopelessness of the reservation; he is surprised to learn that not every white person is a vicious racist. He begins to feel instead that, "The world is only broken into two tribes: The people who are assholes and the people who are not” (Alexie, 2009, p. 176).

Roger, a football player who begins by calling Arnold names like "Tonto", stops insulting him and becomes his friend after Arnold punches him. Throwing the first punch is what you do on the rez when insulted, to keep from getting beaten up worse. But, inexplicably to Arnold, Roger acts like his feelings have been hurt. Arnold is unnerved by the strangeness of Roger's response; if Roger were an Indian, he would be planning revenge, and Rowdy is no longer there to protect Arnold. But Arnold's grandmother tells him not to worry, that he "punched the alpha dog in the face" and "They're going to respect you now" (ibid., p. 70).

Arnold also meets Penelope, who is pretty, smart, and popular, and falls in love or in lust with her. But he gets nowhere until he hears her throwing up in the girl's bathroom, and confronts her about it. Penelope tells him that she is only bulimic when she is throwing up, which sounds just like Arnold's father, who only thinks of himself as an alcoholic when he gets drunk. Arnold sees that "There are all kinds of addicts, I guess. We all have pain. And we all look for ways to make the pain go away... Penelope gorges on her pain and then throws it up and flushes it away. My dad drinks his pain away" (ibid., p. 107). When Penelope tells him that she wants to do more than get married and have babies, she wants to go everywhere and do everything, Arnold asks what she really wants to do. "Make it simple," he says (ibid., p. 111), and she tells him she wants to study architecture. They become closer because they both have dreams, "we both wanted to fly" (ibid., p. 112); but also because Arnold has realized that Penelope is in pain as well. 
Arnold's third and closest friend is Gordy, a farm boy who is an outsider at Reardon because he is so smart. Arnold never gets as close to Gordy as he had been to Rowdy, but Gordy teaches him how to study, and how to read. (In a way, Gordy teaches Arnold more about learning than any of the actual teachers at Reardon.) He tells Arnold that he should "read and draw because really good books and cartoons give you a boner" (ibid., p. 96). In other words, he makes Arnold realize that "hard work - the act of finishing, of completing, of accomplishing a task - is joyous" (ibid., p. 98). Gordy also questions Arnold's assumptions about race. When Arnold says that "you have to act white to make your life better" (ibid., p. 131), Gordy makes the point that, "If that were true, then wouldn't all white people be successful?” (ibid.).

Being at Reardon gives Arnold a chance to deal with his own racism in another context, that of his (unrequited) lust for Penelope. When Arnold emails Rowdy to say he's in love with a white girl, Rowdy emails back that he tired of Indians who treat white women like bowling trophies. When Arnold mentions the same thing to Gordy, Gordy comes right out and tells him he is being a racist asshole.

Later, when Arnold takes Penelope to a dance and has no money to pay for eating at a restaurant afterwards, Roger the football player figures out that Arnold is broke and gives him forty dollars. Penelope asks him straight out if he is poor. Once Arnold tells these two white friends the truth and admits to having no money, he expects them to walk out of his life. Instead, Penelope kisses him. Arnold says: "I realized that she was being my friend. Being a really good friend, in fact. She was concerned about me. I'd been thinking about her breasts and she'd been thinking about my whole life. I was the shallow one" (ibid., p. 127). When she asks him if he's really getting a ride home from his dad and he finally tells her the truth, that no, he isn't, Roger is glad to give him a ride. Later, Roger encourages him to join the basketball team. And although Arnold feels that Roger is still a little bit racist, Arnold also admits that "If you let people into your life a little bit, they can be pretty damn amazing” (ibid., p. 129).

After his sister Mary dies in the trailer fire, Arnold goes to school because he can't stand to be at home with his drunken relatives. He is amazed that so many of the students and teachers come up to him to express their sympathy: "All of these white kids and teachers, who were so suspicious of me when I first arrived, had learned to care about me. Maybe some of them even loved me. And I'd been so suspicious of them. And now I cared about a lot of them. And loved a few of them" (ibid., p. 212).

But Arnold's relationship with his tribe has deteriorated so badly by the time of his grandmother's death that he sees their neutrality towards him as positive: "I would always love them for giving me peace on the day of my grandmother's funeral” (ibid., p. 160). Up until his grandmother's wake the other Indians had either called Arnold names, or shoved him, or pointedly ignored him whenever he was on the rez, which was where he lived, after all. But after his grandma dies, even though he was still the "kid who had betrayed the tribe. And that couldn't be forgiven" (ibid., p. 159), he was no longer the reservation scapegoat, and "they stopped hassling me whenever they saw me" (ibid., p. 160).

In some way Arnold seems to agree with them that what he has done is unforgivable; caught between the two different worlds of Indian and white, it is hard for him to know if what he does is right or wrong. The arrival at his grandma's wake of the wealthy white collector, who is trying to return a stolen, expensive powwow outfit he thinks belonged to Grandma, gives Arnold a way to bond with his tribe. After the white man makes a production of his remorse over never having returned the outfit to Grandma, Arnold's mother tells the man not to worry, her mother was never a powwow dancer so the outfit couldn't have been hers, and it looks like an outfit from the Oglala tribe (Midwestern Plains Indians) anyway. When the man bundles up the valuable outfit and scurries off, "two thousand Indians started laughing" and Arnold thinks: "It was the most glorious noise I'd ever heard” (ibid., p. 166). Sharing laughter at the silly, wealthy, thieving white man, Arnold feels part of the tribe again, and realizes that although Indians are drunk and crazy and mean, they "knew how to laugh" (ibid.).

Arnold doesn't know which side he should stand for, or which side he belongs to, and continues to feel the psychic pressure throughout the book. His wish that Gordy visit the reservation, to tell the rest of the tribe that not every white can be successful, may be a clue to what Arnold wants to hear himself: that his flight from the rez is not a cowardly abandonment of his people, with an easy guarantee of success, but that it was a difficult decision to make, and is an uncertain path to follow. His escape to the white world doesn't ensure an easy life, but it seems to be his only chance at a better one. He wants some acknowledgment that he is taking a risk, and showing courage; that he is being a warrior, not a coward. 


\section{Inner Conflict}

In an interview with Robert Capriccioso, Alexie makes the point that "Indians have not been loved in this country." (Note 6) In Diary he mentions the perils of driving in certain areas off the reservation, where Indians are arrested for the "crime" of Driving While Indian, to give just one example of the racism Native Americans face in the white world. When Arnold's sister marries a Flathead Indian and moves to their reservation in Montana, Arnold says: "Can you imagine a place where the white people are scared of the Indians and not the other way around? That's Montana" (Alexie, 2009, p. 90). Conversely, the Indians on Arnold's reservation seem to believe that if they go into the white world they will be hurt or even killed, as Native Americans have been in the past. They are afraid of whites, it seems with reason.

At Reardon Arnold is initially ostracized. He endures racist taunting from the football player Roger and Roger's friends. Roger goes so far as to tell him a "joke" about Indians being proof that black people have sex with buffaloes. Arnold punches Roger because this is a slur on Indians, blacks, and buffaloes; but he expects to die, as in, be beaten to death, by Roger and his friends.

Later Arnold corrects the science teacher about the composition of petrified wood, and the teacher is furious and verbally abusive until Gordy, the class genius, points out that Arnold is correct. But after Arnold thanks him, Gordy explains that he didn't speak up for Arnold but for science. It is only through Arnold's persistence that he and Gordy later become friends.

In the Capriccioso interview, Alexie stresses that it is not only whites who are intolerant of those who are different from them: "Indian people are very conservative. I don't think you could really tell the social difference between the average reservation Indian and, you know, white farmers.” (Note 7) In Diary, Arnold doesn't want to go to a powwow, even though the dancing and singing are wonderful, because all the "talentless" Indians who can't sing and dance are going to get drunk and beat up anyone who seems odd to them. (This is exactly what happens: three grown men in their thirties make fun of Arnold for his brain disorder, shoving him back and forth between them, and then knee him in the balls, laugh, and walk away.) Later in Diary, Alexie notes with some irony that such intolerance is symptomatic of the loss of their Native American heritage. Arnold admires his grandma because she is accepting of people who are different or "weird", and in the way Indians used to be: in the old days epileptics were often revered as shamans and gays were seen as "magical" (Alexie, 2009, p. 155). Arnold's grandmother doesn't only tolerate differences, but she is genuinely interested in and curious about other people. She is the only person completely in favor of his decision to go to Reardon, because he will meet so many new people. But in this she is not only "traditional”, but exceptional.

In his first months at Reardon, Arnold has the sense of being displaced in the white world. He feels like "a freaky alien and there was absolutely no way to get home" (ibid., p. 66). By the time of basketball try-outs he is beginning to feel safer; he goes one-on-one with Roger, who yells and screams like a madman, but Arnold refuses to be intimidated. When Roger bumps fists with him for beating him, Arnold thinks: "I was a warrior!” (ibid., p. 141)

The basketball games between the Reardon team (ironically enough, they are called The Indians) and the Wellpinit reservation team (the real Indians) are pivotal events in the novel, and highlight the tension not only between the whites and the Indians, but between the two people that Arnold feels himself to be, the two identities he feels forced to choose between. At the first game Arnold has to get up early so his father can drive him twenty-two miles to Reardon, "so I could get on the team bus for the ride back to the reservation" (ibid., p. 142). The physical back and forth shows the literal reality of his sense of moving between two worlds.

Arnold's confusion about his in-between or dual identity is not shared by the Indians on the reservation; quite simply, they see him as a traitor. When he shows up with the Reardon team on the rez, their bus is pelted with snowballs, and a few rocks. As he gets off the bus he can hear the crowd in the gym yelling "Ar-nold sucks!" over and over again. They aren't calling him by his reservation name, which is Junior, but his Reardon name, which is Arnold. They know exactly whom they are angry with. As soon as he walks into the gym, they all fall silent and, as one, turn their backs on him. Only Rowdy faces him, and Rowdy is ready to play basketball; he stares at Arnold with fury. During the game, Arnold is hit in the head with a thrown quarter, goes back on the court despite needing stitches, and then gets knocked out in a scuffle under the backboard with Rowdy. Arnold ends up in the hospital, while the white referees are so cowed by the furious Indians that they call gratuitous fouls on the Reardon team, and Wellpinit wins by 30 points.

By the second game between the two teams, Arnold sees the conflict in Biblical terms, as David and Goliath. Interviewed by a TV crew, he says he will never surrender. He sees the Reardon team as David, the boy with a 
slingshot against a mighty, armed warrior. Since Arnold identifies his team with himself, and they lost so badly (and unfairly) in the previous game, this makes sense to him. Arnold's basketball coach, who has become his mentor, assigns him the task of guarding Rowdy, who is their toughest opponent. When Coach tells him, "You can do it," he reminds Arnold of Eugene, who always believed in him. In the first minutes of the game, feeling aided by the ghosts of his grandma and Eugene, Arnold steals the ball from Rowdy, out-jumping him for the first (and presumably last) time ever, and races away to score a basket. Even though Arnold never scores again, this opening play wins the game for Reardon; it takes the heart out of the Indian team. But at the end of the game when the Reardon team has won, Arnold sees his father looking at the Indian team. Arnold knows that two or three of those Indians don't have any food in the house, that another few have fathers in prison, that one has a father who is dealing meth, and that Rowdy will likely get beaten by his father for losing the game. He realizes that the Indians are David, and his team is Goliath. He says: "I was suddenly ashamed that I'd wanted so badly to take revenge on them...I was crying because I had broken my best friend's heart” (ibid., p. 196). What had felt like a triumph at the time, a refusal to give up, had become a reason for shame and grief.

\section{Conclusion}

At a reading at the Strand bookstore, Alexie said that he wants his readers to experience "escaping and confronting familial and tribal expectations." (Note 8) The character Arnold is lucky to have his family behind him; they love him, and they support his desire for something better, so he has the self-esteem to go for it. Rowdy is not so lucky. After trying to convince Rowdy to come to Reardon and getting punched for his pains, Arnold concedes that he cannot change what people on the rez think about him, any more than he can change the toxic atmosphere of the reservation. Despite his fear of the white world he wants to enter, Arnold is determined to make the attempt, to make his own decision.

While most of Alexie's fiction focuses on the omnipresent alcoholism, poverty, lack of opportunity, and despair that plague Native American reservation life, the main characters in his stories are still struggling to survive. Arnold sees himself and his sister as "warriors" because they are going after their dreams. Diary demonstrates that Arnold's "determination to both improve himself and overcome poverty, despite the handicaps of birth, circumstances, and race, delivers a positive message in a low-key manner.” (Note 9) Even though Alexie leaves the reservation, Diary shows his "love for the strength of its residents" (Korsmo, 2011, p. 8).

Arnold never stops trying to reconcile with Rowdy. He emails Rowdy that he is sorry they beat him at basketball. Earlier, he brings him a cartoon of the two of them as a gift. Although Rowdy refuses to see him, Arnold notices Rowdy in an upstairs window, looking at the cartoon and not tearing it up, and is cheered by this. At the end of the book, when Rowdy comes by, saying it is because he's bored, Arnold has one moment of wishing for an apology, and then is simply happy to see his friend again.

Arnold finds out who he is with his cartoons; Alexie through his stories of "Spokane Indian males...stumbling through life." (Note 10) Since Arnold is modeled on Alexie, it is tempting to assume that the author felt as Arnold does, and wanted to do something for his tribe. In fact, Alexie says that "the social function of art is very important to me. It's not just for art's sake. I have very specific ideas in mind about what it can do...[for instance,] I think reading about alcoholism helps other people stay sober.” (Note 11)

Asked how he feels about writing down some of the harsher truths about people in his tribe, Alexie admits to ambivalence:

I've made mistakes about subject matter, things I probably shouldn't have written about. I wrote about events I shouldn't have written about. . . [but] It's my job to beat the shit out of the world. I'm not here to make people feel good. (Note 12)

But over the years Alexie has gotten a more positive response from Native American readers who feel that his stories have helped them: "at the beginning it was really uncomfortable for them ... so it has come through a cycle - denial, acceptance and now they embrace it." (Note 13) At the end of the day, Alexie says that he intends to convey a message of hope to his young readers: "They see a rez-kid like me doing what I do and they might start thinking, well, I could do that. I am tangible evidence of the possibilities." (Note 14)

In Diary, Arnold is a role model who opens a door between the Indian and the white world through persistence and determination, and a desire to connect (or reconnect) with others. Near the end of the book he achieves a kind of peace when he realizes that although he is lonely he is part of not one, but many tribes - including the tribe of people who leave home to find something better. Arnold never gives up, and Alexie's stories may be seen as exhortations to 
his readers to do the same, to keep on trying and never give up. Arnold refuses to surrender his dreams, but neither will he surrender his feeling for others; the cost seems to be that even after Rowdy has forgiven him for leaving them, Arnold is still trying to forgive himself. Perhaps by giving back to the people he left, Alexie the author has been able to do that.

\section{References}

Alexie, Sherman. (2009/2007). The absolutely true diary of a part-time Indian. New York: Little, Brown and Company.

Bruce, Heather E., Anna E. Baldwin \& Christabel Umphrey. (2008). Sherman Alexie in the classroom. Urbana, Ill.: National Council of Teachers of English.

Connette, Tracey L. (2010). Sherman Alexie's reservation: relocating the center of Indian identity. Thesis. Carolina: East Carolina University.

Evans, Stephen F. (2001). Open containers': Sherman Alexie’s drunken Indians. American Indian Quarterly, 25(1), 46-72. http://dx.doi.org/10.1353/aiq.2001.0004

French, Laurence A., \& Hornbuckle, Jim. (1980). Alcoholism among Native Americans: An analysis. Social Work, 25(4), 275-280.

Korsmo, Jamie. (2011). Leaving the rez': Indigenizing urban space in selected short stories by Sherman Alexie. Diss. Oklahoma: Central Oklahoma University.

Liu, Kedong. (2011). The image of postindian warrior in the absolutely true diary of a part-time Indian. Foreign Literature Studies, 33(6), 92-96.

Nelson, Joshua B. (2010). Fight as flight: The traditional reclamation of exploration. World Literature Today, 84(4), 44-47.

Room, Robin. (2001). Intoxication and bad behavior: Understanding cultural differences in the link. Social Science \& Medicine, 53, 189-198. http://dx.doi.org/10.1016/S0277-9536(00)00330-0

\section{Notes}

Note 1. See http://www.nytimes.com/2009/10/21/books/21alexie.html

Note 2. See http://www.bigthink.com/videos/big-think-interview-with-sherman-alexie

Note 3. See http://www.aafp.org/afp/1999/0115/p361.html

Note 4. See http:// www.indiana.edu/ rcapub/v17n3/p18.html

Note 5. See http://www.bigthink.com/videos.big-think-interview-with-sherman-alexie

Note 6. See http://www.identitytheory.com/sherman-alexie-interview

Note 7. Ibid.

Note 8. See http://zh.scribd.com/doc/133248098/The-Absolutely-True-Diary-of-a-Part-1

Note 9. See http://www.maldenreads.org/CRITICALACCLAIM.html

Note 10. See bigthink.com interview.

Note 11. Ibid.

Note 12. See http://www.identitytheory.com/sherman-alexie-interview

Note 13. Ibid.

Note 14. Ibid. 